\title{
Molecular Mechanisms of the Acute Kidney Injury to Chronic Kidney Disease Transition: An Updated View
}

\author{
Francesco Guzzi ${ }^{1,2,3, *(\mathbb{D})}$, Luigi Cirillo ${ }^{3}$, Rosa Maria Roperto ${ }^{3}$, Paola Romagnani ${ }^{1,2,3}$ and \\ Elena Lazzeri ${ }^{1,2}$
}

1 Excellence Centre for Research, Transfer and High Education for the development of DE NOVO Therapies (DENOTHE), University of Florence, 50139 Florence, Italy; paola.romagnani@unifi.it (P.R.); elena.lazzeri@unifi.it (E.L.)

2 Department of Experimental and Clinical Biomedical Sciences "Mario Serio", University of Florence, 50134 Florence, Italy

3 Nephrology and Dialysis Unit, Meyer Children's University Hospital, 50139 Florence, Italy; cirlui89@gmail.com (L.C.); rosa.roperto@meyer.it (R.M.R.)

* Correspondence: francesco.guzzi@gmail.com

Received: 19 September 2019; Accepted: 4 October 2019; Published: 6 October 2019

\begin{abstract}
Increasing evidence has demonstrated the bidirectional link between acute kidney injury (AKI) and chronic kidney disease (CKD) such that, in the clinical setting, the new concept of a unified syndrome has been proposed. The pathophysiological reasons, along with the cellular and molecular mechanisms, behind the ability of a single, acute, apparently self-limiting event to drive chronic kidney disease progression are yet to be explained. This acute injury could promote progression to chronic disease through different pathways involving the endothelium, the inflammatory response and the development of fibrosis. The interplay among endothelial cells, macrophages and other immune cells, pericytes and fibroblasts often converge in the tubular epithelial cells that play a central role. Recent evidence has strengthened this concept by demonstrating that injured tubules respond to acute tubular necrosis through two main mechanisms: The polyploidization of tubular cells and the proliferation of a small population of self-renewing renal progenitors. This alternative pathophysiological interpretation could better characterize functional recovery after AKI.
\end{abstract}

Keywords: acute kidney injury; chronic kidney disease; renal progenitors; polyploidization

\section{AKI Is Not a Self-Limiting Event}

Despite the common belief of a generally benign nature, the profound, long-term implications of acute kidney injury (AKI) are appearing more and more evident. In particular, the emergent finding of a progression to various degrees of chronic kidney disease (CKD) after apparently self-limiting AKI episodes, independent from the etiology, has attracted great attention.

In the last decade, the assumption of an existing association between AKI and CKD has gradually spread in the nephrology and intensive care fields with evidence of a tight link between even mild serum creatinine elevation and long-term CKD [1-3]. The classic teaching case regarding acute renal failure, in particular acute tubular necrosis (ATN), has been that those patients generally achieve full or nearly full recovery [4,5]. The consensus on a new definition of AKI has helped to improve the understanding of its long-term clinical consequences and to demonstrate a clear link between AKI episodes, their severity, and their outcome [6]. With the help of standardized criteria for the definition of AKI and CKD, diverse observational studies collecting data from large administrative databases have increasingly showed a possible association between these two clinical entities [7-9]. Indeed, the more recent assumption is now to consider AKI and CKD as two interconnected syndromes 
where CKD is a risk factor for AKI and, in the meantime, AKI is a risk factor for the development and progression of CKD [3]. A recent systematic review and meta-analysis by See et al. [7] aimed to quantify the association between AKI and CKD by evaluating the results from 82 studies comprising more than 2 million patients experiencing AKI. The authors confirmed an increase in the risk of new or progressive CKD after AKI (HR 2.67, 95\% CI 1.99-3.58) with a gradient of risk across AKI stages, an increased risk of end stage renal disease (ESRD) (HR 4.81, 95\% CI 3.04-7.62), and an increased risk of death (HR 1.80, 95\% CI 1.61-2.02) [7]. Moreover, previous studies have demonstrated that AKI severity [10], duration [11] and frequency [12] are associated with an increased risk of CKD progression. The AKI-CKD link has also been highlighted in pediatric studies [13-15].

Despite continuous progresses in the field and the recent ability to better identify the molecular signature of different renal cell types following acute injury, the mechanisms that drive the transition to chronic disease remain debated $[16,17]$. The traditional beliefs are now challenged by clinical observations and new advances in experimental transgenic models. Researchers have made significant effort trying to elucidate the pathophysiological link from AKI to CKD on cellular and molecular levels by using experimental models. CKD can occur through several pathologic mechanisms involving one or more of the kidney compartments: Vasculature, the tubule-interstitium or the glomerulus. Microvascular loss occurs along with increased fibrosis, worsening relative hypoxia within the kidney and in particular within the outer medulla. This is associated with changes in pericytes to adopt a pro-fibrotic myofibroblast phenotype. Moreover, consequent to altered oxygen availability, tubular injury and necrosis cause tubular dysfunction, oliguria and reduced glomerular filtration via tubulo-glomerular feedback. Thus, after an ischemic injury, the loss of nephronic mass, with remnant nephron hyperfiltration, renin-angiotensin system (RAS) activation, systemic hypertension and subsequent glomerulosclerosis have been described to pave the way from AKI to CKD [18-20]. Regardless of the initial insult, evidence of tubular cell loss and replacement by collagen scars and infiltrating macrophages are associated with further renal functional loss and progression towards end stage renal failure. Experimental models have shown that selective epithelial injury could drive capillary rarefaction, interstitial fibrosis, glomerulosclerosis and progression to $\mathrm{CKD}$, substantiating a direct role for damaged tubular epithelial cells (TECs) [21]. Therefore, tubular epithelial cells have attracted increasing attention $[22,23]$.

A new interpretation of this pathophysiology is that the epithelial tubular cell may allow for a better understanding of this somehow unexpected turn in the AKI natural history. Altogether, there is a need for the further investigation of the AKI-to-CKD transition as a public health priority.

\section{Pathophysiology of the AKI-to-CKD Transition}

From a pathophysiological point of view, microvascular integrity, changes in leukocyte and pericyte behavior, and tubular cell survival and function are all features of both AKI and CKD, and several cellular and molecular pathways have been considered to define the transition process. The main pathological mechanisms which concur to explain the AKI-to-CKD transition include: (i) Endothelial dysfunction, vasoconstriction and vascular congestion [24,25]; (ii) interstitial inflammation and the associated infiltration of monocytes/macrophages, neutrophils, T- and B-cells [26-30]; (iii) fibrosis via myofibroblasts recruitment and matrix deposition [31-33]; and (iv) tubular epithelial injury and dysregulated repair [23,34,35] (Figure 1). After a brief description of the main molecular pathways of the endothelial, inflammatory and fibrotic response to injury, we focus on the proximal tubular epithelial cell, the main player of the AKI-to-CKD transition [35]. 


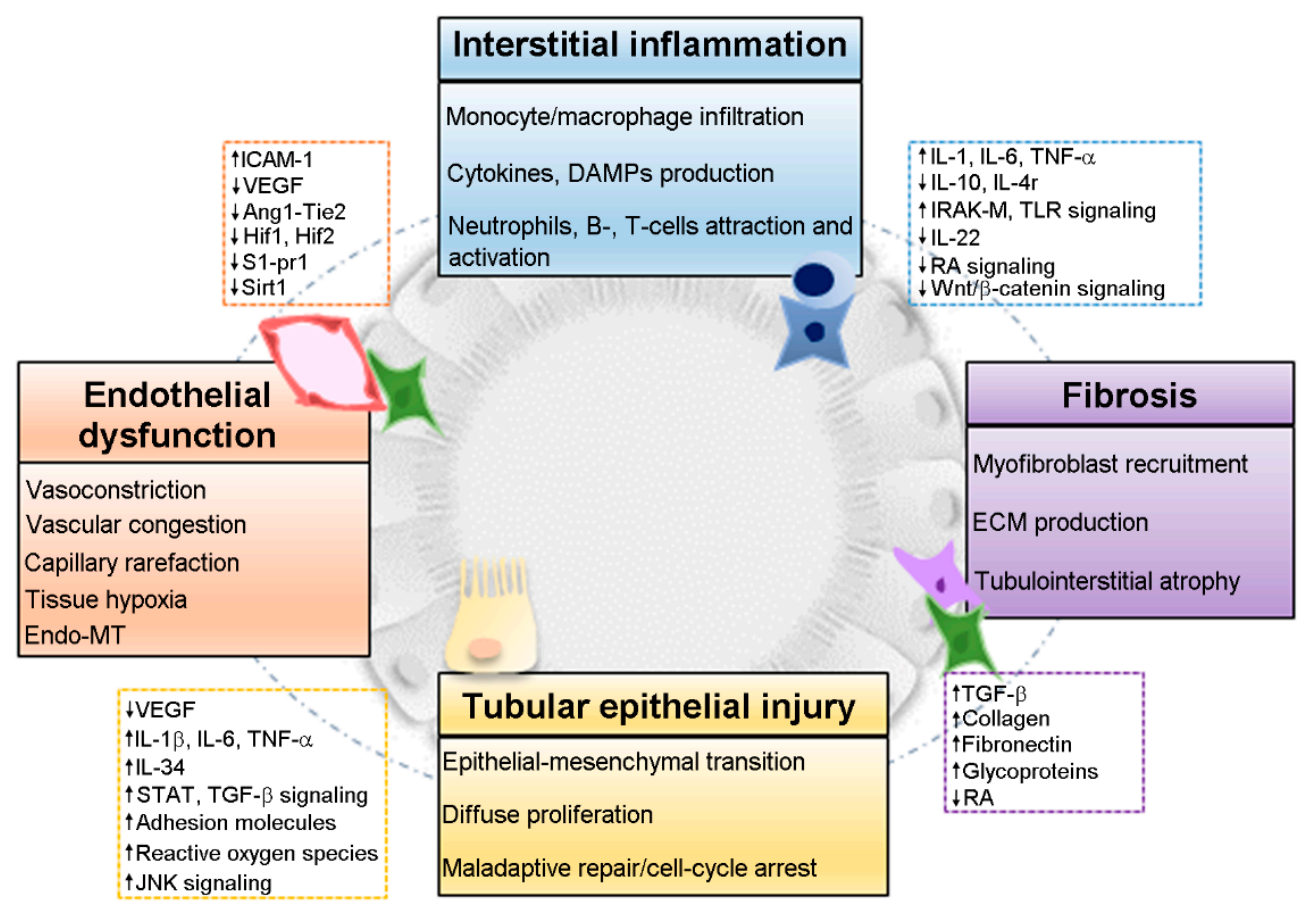

Figure 1. The interplay between endothelial dysfunction, interstitial inflammation, fibrosis and tubular epithelial injury concur to explain the acute kidney injury-to-chronic kidney disease (AKI-to-CKD) transition.

\subsection{Endothelial Dysfunction}

Capillary rarefaction has been extensively described as a consistent feature of the acutely injured nephron and has been linked to progression as a potential initiator of chronic nephropathy. A reduction in regional renal oxygen delivery leads to inflammation, ischemia, and necrosis, thus reflecting an imbalance between arterial pressure and vascular resistance, with a particularly vulnerable area in the outer stripe of the outer medulla. The existence of a putative bone marrow-derived endothelial progenitor cell (EPC) population has been hypothesized and linked to progression to chronic disease [36]. However, a recent study that combined bone marrow and kidney transplantation in a transgenic murine model demonstrated that no extra-renal cells substantially contribute to endothelial repair after selective injury [37].

Once capillary rarefaction is established, tissue hypoxia, mitochondrial dysfunction, inflammation and subsequent fibrosis occur [24]. The cellular and molecular pathways that underlie capillary rarefaction - in particular, the interplay between hypoxia, anti-angiogenic, and angiogenic factors-have yet to be explained [38]. Among angiogenic factors, vascular endothelial growth factor (VEGF), an endogenous cytokine produced by epithelial cells and directed to endothelial cells, is crucial for the preservation of vascular networks. Its reduced production could promote microvascular dysfunction and morphologic changes in the nephron [39,40]. The effects of its exogenous administration, with restoration of the microvascular density, improved renal blood flow, and reduced fibrogenic activity have been described in swine kidneys [41]. Similar effects, with improved endothelial cell survival and prevention of capillary leakage, resulted from the activation of the endothelium-specific receptor Tie2 through angiopoietin-1 (Ang-1)—a protein produced by vasculature support cells and specialized pericytes [42]. Moreover, the transgenic murine inactivation of endothelial hypoxia-inducible factors (Hif1- $\alpha$ and Hif2- $\alpha$ ), as well as the deletion of endothelial sphingosine 1-phosphate receptor 1 (S1-pr1), resulted in increased acute and chronic inflammation and fibrosis after injury without affecting capillary permeability $[43,44]$. Therefore, there is considerable interest in the potential for Hif-stabilizing agents as therapeutic tools in renal injury [45]. In two models 
of folic acid-induced AKI and ureteral obstruction, Sirtuin 1 (Sirt 1) inactivation in endothelial cells caused impaired recovery, increased fibrosis, and disease progression [46,47].

Endothelial-to-mesenchymal transition (EndoMT) has been proposed as a contributor to capillary rarefaction, interstitial fibrosis, and, therefore, chronic damage [48]. Indeed, the reduction of EndoMT, obtained by reducing endothelium-specific transforming growth factor $\beta$ (TGF- $\beta$ ) in a transgenic mouse model, was followed by the preservation of renal blood flow and microvasculature, less tissue hypoxia and tubulointerstitial fibrosis, thereby supporting the hypothesis of a link between EndoMT and chronic changes [49]. Moreover, the renal pericyte is now recognized as a key contributor to vascular stability in response to kidney injury [50].

Pericytes sit in close proximity to the endothelial cells within many organs, where they maintain vascular stability and release factors, including PDGF (platelet-derived growth factor) [51], angiopoietin [52], TGF- $\beta$ [53], VEGF [54] and sphingosine-1-phosphate [55]. There is now an increasing understanding of the role played by these cells in acute and chronic kidney injury, where they leave their perivascular site in response to injury and differentiate to become myofibroblasts. Thus, either injuries or defects in pericyte function induce their detachment, contributing to both vascular rarefaction and increased fibrosis. In the end, recent advances have elucidated a contribution of endothelial cells and their products to capillary rarefaction, inflammation and tubulogenic pathways in a complex cellular interplay [43,44].

\subsection{Interstitial Inflammation}

Both resident and infiltrating immune cells participate in inflammation, injury and repair in the acute phase of kidney injury; through a tight cross-talk with endothelial cells, epithelial cells, and pericytes, they also contribute to disease progression [56]. The recent identification of a particular subset of renal resident macrophages, located at the abluminal side of the peritubular capillaries and capable of monitoring endothelial transport, has provided a perfect paradigm of the interplay between endothelium and immune system [57]. Resident macrophages seem to form a distinct anatomical and functional unit with the peritubular capillary endothelial cells that have the ability to detect and scavenge small immune complexes, possibly explaining the further recruitment of monocytes and neutrophils, as well as tissue injury in immune complex diseases [57]. This macrophage-endothelial functional unit, with a specific cross-talk at both the cellular and molecular levels, is also likely to be involved in the response to AKI [38].

The link between endothelial cells and inflammation is also suggested by CD169+ monocytes/macrophages that counteract the inflammatory response induced by intercellular adhesion molecule-1 (ICAM-1) expression after ischemic AKI [58]. Because they regulate inflammation, neutrophils infiltration, and because of their paracrine effects on tubular epithelial cells, macrophages can play an important role as determinants of AKI outcomes. Two populations of macrophages have been proposed by in vitro studies on behalf of their chemokine receptor repertoire: Pro-inflammatory or M1-subtype (interleukin (IL)-1, IL-6, and tumor necrosis factor- $\alpha$ (TNF- $\alpha$ )) and anti-inflammatory or M2-subtype (arginase, mannose receptor, IL-10, and IL-4 receptor- $\alpha$ ), the first classically activated and the latter alternatively activated [59]. Despite being recently revised in regards to these two populations' in vivo behavior $[60,61]$, this classification has been useful to identify different responses after acute injury in the kidney and a putative role for these cells in disease progression [28]. Macrophages have contrasting roles in renal injury and repair, first increasing the number of M1-polarized cells and then switching to an M2 phenotype supporting epithelial cell repair. Indeed, the depletion of M2 macrophages in mice with established AKI has resulted in prolongation of renal injury [62].

In a post-ischemic transgenic murine model, IL-1 receptor-associated kinase-M (IRAK-M), specifically expressed by monocyte/macrophages, has been demonstrated to influence the progression of AKI to CKD. IRAK-M expression induces the healing phase by inhibiting the toll-like receptor (TLR) and IL-1 receptor signaling, resolving TNF- $\alpha$-dependent inflammation, and dampening the M1 pro-inflammatory response, all of which have been found to allow for improved functional recovery 
and structural regeneration [26]. Macrophages also participate in endogenous repair by secreting cytokines, such as IL-22, and providing ligands for retinoic acid (RA) and $W n t / \beta$-catenin. In an ischemia-reperfusion injury (IRI) transgenic murine model, the administration or overexpression of IL-22 has been found to preserve renal function by increasing signal transducer and transcription factor 3 (STAT3) and protein kinase B (Akt) phosphorylation in proximal tubular epithelial cells, upregulating anti-apoptotic genes (e.g., Bcl-2), and downregulating pro-apoptotic genes (e.g., Bad) [63]. Retinoic acid (RA) signaling, activated in macrophages and tubular epithelial cells within hours of injury, has been found to reduce macrophage-dependent injury and fibrosis after AKI [64]. In zebrafish and murine models, the activation of RA signaling between epithelial cells and macrophages after AKI has been found to limit the injury extent by promoting the activation of M2 macrophages and tubular epithelial cell repair [64]. Wnt/ $\beta$-catenin is another important pathway in recovery from AKI. Its activation by macrophages has been found to stimulate repair [65], and its early intervention is required to minimize renal damage after AKI in the initial phase [66]. However, its persistent activation and Wnt1 overexpression have been shown to play a role in progression to CKD through uncontrolled fibroblasts activation and inflammation $[66,67]$. Therefore, while important in facilitating repair after AKI, the presence of macrophages is also correlated with fibrosis and adverse outcomes. Moreover, the reciprocal expression of colony-stimulating factor-1 (CSF-1) and its receptor between macrophages and tubular epithelial cells could enhance cell proliferation and stimulate the anti-inflammatory M2 subtype [68]. Interestingly, to highlight the complexity of the interplay between these cells upon injury, IL-34 produced by injured TECs may have a pro-inflammatory ability despite sharing the same macrophage receptor of CSF-1 [69].

After the initial phase of injury, early inflammation is followed by the infiltration of circulating immune cells (T- and B-cells) attracted by cytokines and damage-associated molecular patterns (DAMPs) released by injured cells [27]. While interacting with activated monocytes/macrophages, injured TECs, and endothelial cells, DAMPs participate in the development of a pro-fibrotic milieu which activates pericytes to proliferate and evolve into myofibroblasts, thereby inducing matrix deposition, renal fibrosis, and CKD [70]. In contrast, a subset of regulatory T-cells (Treg) may act like self-tolerance inducers and suppress inflammation by enhancing immune homeostasis [71]. Together with their positive effects, Treg depletion has been shown to aggravate ischemic AKI [72]. Interestingly, the protective role of CD4+ and CD8+ T-cells in a murine model of toxic nephropathy (aristolochic acid nephropathy) has recently been described after treatment with selective monoclonal antibodies [73]. Concerning B-cells, immunoglobulins production, antigen presentation, and subsequent complement activation have been described as possible contributors to the progression from acute to chronic renal injury [74].

\subsection{Fibrosis}

Several obstructive, ischemia-reperfusion and nephrotoxic animal models have investigated the link between AKI and CKD by focusing on the development of interstitial fibrosis [31-33]. Myofibroblasts, whether derived from activated resident fibroblasts or from pericytes, are responsible for extracellular matrix (ECM) production, with the deposition of collagens, fibronectins and other glycoproteins, which, together with TGF- $\beta$, contribute to fibrosis [32,75]. The expression of $\alpha$-smooth muscle actin ( $\alpha$-SMA), usually confined to the vascular compartment, and platelet-derived growth factor receptor- $\beta$ (PDGFR- $\beta$ ), identifies these cells in the interstitium of injured kidneys [75]. A number of studies have consistently linked peritubular capillaries rarefaction, pericytes detachment, interstitial hypoxia and tubular epithelial injury as triggers of renal fibrosis [21,50]. In particular, whereas an ischemic injury could be responsible for capillary rarefaction and pericyte detachment, pericyte loss could be a trigger for endothelial damage and capillary rarefaction followed by tubular epithelial injury and fibrosis [50]. Though the severity of interstitial fibrosis in renal biopsies has been recognized as the major prognostic factor for CKD/ESRD, fibrosis has been considered a self-sustaining process [76], 
and a causal relationship between ECM deposition, fibrosis and chronic kidney injury has not yet been identified.

Recent studies have suggested that fibrosis could also be beneficial for the healing processes [34]. During repair from experimental AKI, tubules that fail to recover become atrophic, and fibrosis surrounds them in well-demarcated areas that separate the injured parenchyma from restored or not injured tubules [34]. In this view, fibrosis is itself essentially a self-limiting repair process that restricts injury, and it is not autonomously progressive. Indeed, many other experimental data do not support a major role of self-perpetuating tubulointerstitial fibrosis in the transition from AKI to CKD and highlight that progressive renal fibrosis requires additional injuries-unless primary interstitial disease is itself the triggering factor for fibrosis [23,77]. Recently, in a transgenic mouse model expressing diphtheria toxin receptor on renal fibroblasts, Nakamura et al. showed that fibroblasts depletion could worsen the expression of tubular injury markers, with a marked increase after unilateral ureteral obstruction [33]. While the transition of resident fibroblasts to myofibroblasts has been described to trigger fibrosis [78], myofibroblasts can also acquire retinoic acid-production ability-lost by the injured tubular epithelial cells—supporting epithelial integrity and repair [33] and dampening pro-inflammatory macrophages [64]. In the aged kidney, the ability of resident fibroblasts to support repair is less pronounced [79].

Altogether, a deeper understanding of the cellular and molecular pathways involving fibrosis in different types of acute kidney injury will be of great importance for the development of therapeutic strategies to halt the progression of AKI to CKD [80,81].

\subsection{Tubular Epithelial Injury}

The most sensitive cells to acute ischemic and nephrotoxic injury are the proximal S3 segment tubular epithelial cells of the outer stripe of the outer medulla due to their intense workload, high metabolic demand, and limited capacity for anaerobic energy production [82]. In fact, this region accounts for a unique microvascular environment which is extremely vulnerable to hypoperfusion, renal hypoxia, and mitochondrial damage [82,83]. Recently, a shift from a victim to the driving force of the AKI-to-CKD transition has been proposed for the tubular epithelial cell [35]. Indeed, injured TECs have been shown to act as drivers of both inflammation and fibrosis. They produce a large variety of cytokines (e.g., IL-6, IL-1 $\beta$, and TNF- $\alpha$ ), thereby gaining a pro-inflammatory phenotype and directly influencing macrophage behavior $[84,85]$, and they are an important source of chemokines-via several pathways including STAT signaling and TGF- $\beta$ signaling-adhesion molecules and reactive oxygen species [35]. Traditionally, injured TECs have been thought to undergo a process of dedifferentiation, a partial epithelial-mesenchymal transition (EMT) [86,87], i.e., the de novo expression of mesenchymal marker such as vimentin in TECs [88] induced by the injury-mediated reactivation of snail family zinc finger 1 (Snail1) $[89,90]$. This transient dedifferentiation is also characterized by the re-expression of developmental genes such as Pax 2 and cell cycle markers such as proliferating cell nuclear antigen (PCNA) - thus suggesting extensive proliferation-followed by a loss of mesenchymal markers, which has been interpreted as re-differentiation into fully viable epithelial cells [91,92]. This extensive proliferative ability could be responsible for rapid repair upon acute injury.

This proliferative capacity is thought to explain why young and mildly injured patients regain normal (or near-normal) renal function within days from acute injury, regardless of etiology. According to this view, the kidney's reparative potential is counterbalanced by maladaptive repair, as if they are on a balance pan. Shifting from proliferation to maladaptive repair would explain disease progression. In one toxic and one obstructive nephropathy models, Yang et al. demonstrated a causal association between cell cycle arrest and fibrosis [93]. Due to abnormal repair processes, TECs can become atrophic and gain a pro-fibrotic phenotype after AKI. G2/M-arrested TECs may activate the JNK signaling to induce the production of pro-fibrotic cytokines (e.g., TGF- $\beta$ and connective tissue growth factor (CTGF)) [22]. Altogether, whereas favorable cell cycle events could be responsible for repair, cell cycle arrest could determine the progression of injury. Dysregulated and inefficient (i.e., maladaptive) 
tubular repair has been related to the persistence of an inflammatory milieu, ECM deposition and subsequent tubular cells convergence towards a pro-fibrotic and senescent phenotype [94]. Indeed, dedifferentiated TECs acquire pro-fibrotic characteristics that elicit CKD progression [23].

An alternative pathophysiological interpretation of cell cycle events after acute injury has recently been proposed $[95,96]$. Indeed, several studies have recently pointed toward the existence of a scattered population of undifferentiated, self-renewing, renal progenitors with the ability to regenerate fully differentiated TECs rather than acquire a dedifferentiation state [97-102]. After their identification in the human kidney, further studies were able to provide detailed characterization in both humans and mice [100] and to identify these cells as a source of tubular regeneration after AKI [103]. This strategy for kidney regeneration appears to be highly conserved across species [104] and involved in kidney development, maintenance, and regeneration [105]. New experimental evidence provided by lineage tracing studies has strengthened the concept that tubular epithelial cell regeneration is mostly due to a scattered progenitors' population rather than to the majority of remnant cells [95]. Renal progenitors are more numerous in the proximal tubule S3 segment, the segment which is more sensitive to ischemic and nephrotoxic injury and from where tubular cells detach in large numbers, thus explaining the high proliferation of tubular epithelial cells observed in this area (Figure 2) [95]. The intense immunoreactivity of nuclear proliferation markers (such as proliferating cell nuclear antigen-PCNA and Ki-67) has also been observed after acute injury in the proximal tubule S2 segment and other uninjured areas of the nephron $[88,106]$. Regardless, although such cell cycle markers confirm the cell's entry in the cell cycle, they do not entail its completion with the formation of two new differentiated daughter cells. Thanks to simultaneous cell cycle phase lineage tracing analysis and DNA content measurement with FUCCI (fluorescent ubiquitination-based cell cycle indicator) technology, it has been shown that the majority of remnant TECs do enter the cell cycle, but they undergo endoreplication-mediated hypertrophy (Figure 2). Endoreplication is an evolutionary conserved cell cycle program by which cells replicate their genome without division, resulting in polyploid cells (i.e., polyploidization). Polyploidization increases the gene copy number in response to the need to quickly support increased functional requests for a higher metabolic output while persistently maintaining differentiated and specialized cell functions. This permits hypertrophy and function recovery $[95,96]$.

In mammals, endoreplication-induced polyploidy has been observed in multiple tissue and organs (including the skin, placenta, liver, and blood) during normal development and under stressful conditions [107]. In the kidney, tubular cell polyploidization has frequently been observed in the proximal convoluted tubule S2 segment that is not directly injured during ATN (Figure 2). Accordingly, a new interpretation could follow: i) AKI causes TEC loss; ii) a small subset of progenitor cells showing resistance to death and proliferative ability are responsible for parenchymal regeneration; and iii) remnant TECs enter the cell cycle but undergo endoreplication-mediated polyploidy rather than mitosis, thus rapidly compensating for function loss [95].

According to this new hypothesis, the physiological response to AKI could imply a limited regeneration mediated by scattered renal progenitors and a polyploidization response by remnant TECs [96]. Polyploid TECs do not truly reconstitute parenchymal loss; thus, they might be a marker of irreversible loss and elicit progression towards chronic disease. In this view, a response to AKI is a costly process which cannot endlessly repeat without any consequence; rather, the tubular epithelium is more susceptible to further damage after every hit, better mirroring the clinical spectrum of the AKI-to-CKD transition. 
A
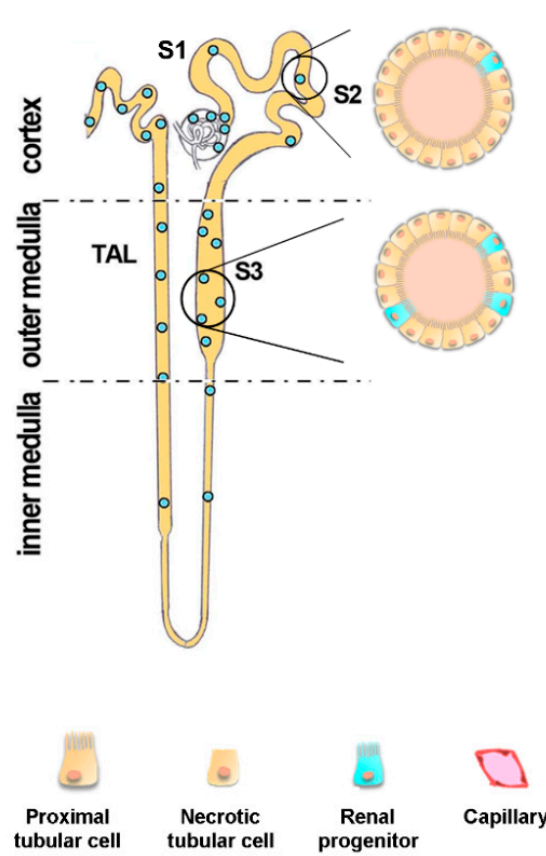

B

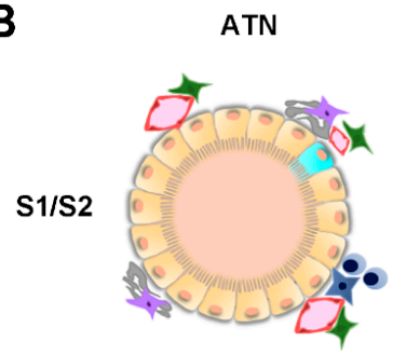

S3

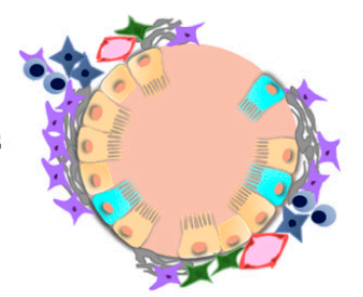

Pericyte

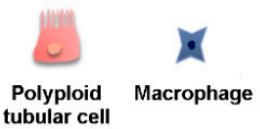

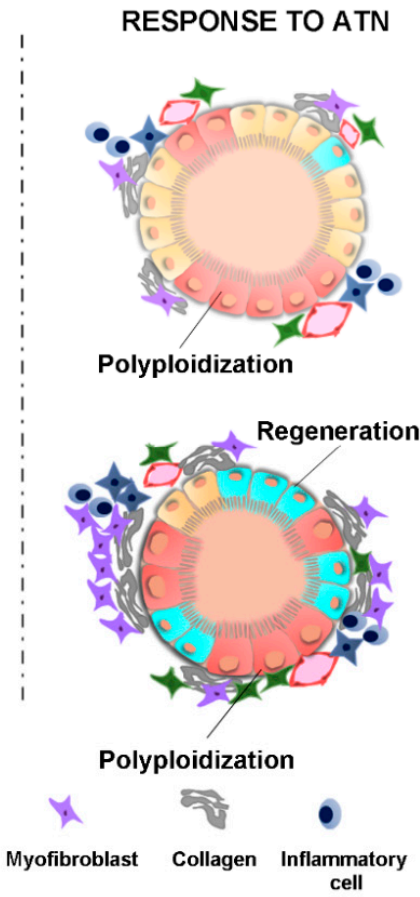

Figure 2. A new pathophysiological interpretation of tubular response to AKI leading towards CKD: The proliferation of renal progenitors and polyploidization of tubular cells. (A) Schematic localization of renal progenitors scattered along the S1-S2 segment, the S3 segment, and thick ascending limb (TAL) in the nephron. (Figure modified from Lazzeri et al., Trends Mol Med, 2019); (B) Top: In the uninjured proximal tubule S1-S2 segment, tubular epithelial cells enhance their working capacity by entering the cell cycle to increase their DNA content without division, resulting in polyploid tubular cells (i.e., polyploidization). Bottom: In the necrotic proximal tubule S3 segment, renal progenitors proliferate and complete cell division to drive regeneration, while the remnant tubular epithelial cells undergo polyploidization rather than mitosis. ATN: Acute tubular necrosis.

\section{Conclusions}

A tight link between AKI and CKD is now becoming evident, both in the clinical and experimental settings. AKI severity, duration and frequency are associated with the development of CKD, but even mild episodes are associated with an increased risk of disease progression. Recent experimental findings have provided new insight into the cellular and molecular mechanisms of the AKI-to-CKD transition; these experiments have been trying to unveil the relative contribution of endothelial dysfunction, immune cell response, pericytes and fibroblasts activation. Regardless of the AKI etiology, endothelial dysfunction and subsequent hypoxia (as well as death of tubular cells from a toxic injury) trigger a cascade of self-sustaining events involving myofibroblast activation derived from resident fibroblasts or pericytes, extracellular matrix deposition, and interstitial inflammation. The overall view has shown that all the molecular and cellular mechanisms converge to the tubular epithelial cell dysfunction. Indeed, the lack of recovery of the tubular structure's integrity sustains the above-mentioned events, thus promoting the progression of interstitial injury. The direct increase in the risk of CKD development and progression, which mirrors the severity of the acute episode, suggests a causative role of the final effector of acute function loss, i.e., epithelial cell injury. In several highly specialized organs, widespread parenchymal proliferation is likely to be a counterproductive strategy. Indeed, the mitosis and cytokinesis of highly specialized parenchymal cells determines a temporary loss of function that might become critical for the organ's survival. It is now becoming evident that, to minimize the mitotic ability of specialized parenchymal cells without losing their functional performance, evolution has selected an alternative type of response: Hypertrophy via polyploidization. 
The biological rationale for increasing genome content through polyploidization could be to increase cell size and to facilitate amplified cell metabolism so that polyploid cells could sustain acute organ function recovery. Renal progenitor cells instead, thanks to their clonogenic ability, could be responsible for the true tissue regeneration and structural recovery of the necrotic S3 segment of the proximal tubule in affected nephrons, as highlighted by lineage tracing studies. Overall, these results suggest that injured tubules respond to ATN through two main mechanisms: The polyploidization of tubular cells and the proliferation of renal progenitors. New advances in the understanding of the biology and pathophysiology of epithelial tubular cells, renal progenitors, and their adaptation mechanisms will permit the better characterization of functional recovery after AKI and the tracing of the cascade of events leading towards CKD.

Author Contributions: F.G. and E.L. wrote the paper; F.G., L.C., R.M.R., P.R. and E.L. critically revised the manuscript.

Funding: This manuscript is supported by the European Research Council under the Consolidator Grant RENOIR to Paola Romagnani (ERC-2014-CoG), grant number 648274.

Conflicts of Interest: The authors declare no conflict of interest.

$\begin{array}{ll}\text { Abbreviations } \\ \text { AKI } & \text { Acute kidney injury } \\ \text { Akt } & \text { Protein kinase B } \\ \text { Ang-1 } & \text { Angiopoietin-1 } \\ \text { ATN } & \text { Acute tubular necrosis } \\ \text { CKD } & \text { Chronic kidney disease } \\ \text { CSF-1 } & \text { Colony-stimulating factor-1 } \\ \text { CTGF } & \text { Connective tissue growth factor } \\ \text { DAMPs } & \text { Damage-associated molecular patterns } \\ \text { ECM } & \text { Extracellular matrix } \\ \text { EMT } & \text { Epithelial-mesenchymal transition } \\ \text { EndoMT } & \text { Endothelial to mesenchymal transition } \\ \text { EPC } & \text { Endothelial progenitor cells } \\ \text { ESRD } & \text { End stage renal disease } \\ \text { FUCCI } & \text { Fluorescent ubiquitination-based cell cycle indicator } \\ \text { Hif } & \text { Hypoxia-inducible factor } \\ \text { ICAM-1 } & \text { Intercellular adhesion molecule-1 } \\ \text { IL } & \text { Interleukin } \\ \text { IRAK-M } & \text { IL-1 receptor-associated kinase-M } \\ \text { IRI } & \text { Ischemia-reperfusion injury } \\ \text { PCNA } & \text { Proliferating cell nuclear antigen } \\ \text { PDGF } & \text { Platelet-derived growth factor } \\ \text { PDGFR- } \beta & \text { Platelet-derived growth factor receptor- } \beta \\ \text { RA } & \text { Retinoic acid } \\ \text { RAS } & \text { Renin-angiotensin system } \\ \text { S1-pr1 } & \text { Sphingosine 1-phosphate receptor 1 } \\ \text { Sirt 1 } & \text { Sirtuin 1 } \\ \text { Snail1 } & \text { Snail family zinc finger 1 } \\ \text { STAT3 } & \text { Signal transducer and transcription factor 3 } \\ \text { TEC } & \text { Tubular epithelial cell } \\ \text { TGF- } \beta & \text { Transforming growth factor } \beta \\ \text { TLR } & \text { Toll-like receptor } \\ \text { TNF- } \alpha & \text { Tumor necrosis factor- } \alpha \\ \text { VEGF } & \text { Vascular endothelial growth factor } \\ \alpha-S M A & \alpha \text {-smooth muscle actin } \\ & \end{array}$




\section{References}

1. Ponte, B.; Felipe, C.; Muriel, A.; Tenorio, M.T.; Liaño, F. Long-term functional evolution after an acute kidney injury: A 10-year study. Nephrol. Dial. Transplant. Off. Publ. Eur. Dial. Transpl. Assoc.-Eur. Ren. Assoc. 2008, 23, 3859-3866. [CrossRef] [PubMed]

2. Coca, S.G.; Singanamala, S.; Parikh, C.R. Chronic kidney disease after acute kidney injury: A systematic review and meta-analysis. Kidney Int. 2012, 81, 442-448. [CrossRef] [PubMed]

3. Chawla, L.S.; Eggers, P.W.; Star, R.A.; Kimmel, P.L. Acute kidney injury and chronic kidney disease as interconnected syndromes. N. Engl. J. Med. 2014, 371, 58-66. [CrossRef] [PubMed]

4. Lowe, K.G. The late prognosis in acute tubular necrosis. Lancet 1952, 259, 1086-1088. [CrossRef]

5. Liaño, F.; Felipe, C.; Tenorio, M.-T.; Rivera, M.; Abraira, V.; Sáez-de-Urturi, J.-M.; Ocaña, J.; Fuentes, C.; Severiano, S. Long-term outcome of acute tubular necrosis: A contribution to its natural history. Kidney Int. 2007, 71, 679-686. [CrossRef] [PubMed]

6. Ricci, Z.; Cruz, D.N.; Ronco, C. Classification and staging of acute kidney injury: Beyond the RIFLE and AKIN criteria. Nat. Rev. Nephrol. 2011, 7, 201-208. [CrossRef] [PubMed]

7. See, E.J.; Jayasinghe, K.; Glassford, N.; Bailey, M.; Johnson, D.W.; Polkinghorne, K.R.; Toussaint, N.D.; Bellomo, R. Long-term risk of adverse outcomes after acute kidney injury: A systematic review and meta-analysis of cohort studies using consensus definitions of exposure. Kidney Int. 2019, 95, 160-172. [CrossRef]

8. Ishani, A.; Xue, J.L.; Himmelfarb, J.; Eggers, P.W.; Kimmel, P.L.; Molitoris, B.A.; Collins, A.J. Acute kidney injury increases risk of ESRD among elderly. J. Am. Soc. Nephrol. 2009, 20, 223-228. [CrossRef]

9. Amdur, R.L.; Chawla, L.S.; Amodeo, S.; Kimmel, P.L.; Palant, C.E. Outcomes following diagnosis of acute renal failure in U.S. veterans: Focus on acute tubular necrosis. Kidney Int. 2009, 76, 1089-1097. [CrossRef]

10. Ishani, A.; Nelson, D.; Clothier, B.; Schult, T.; Nugent, S.; Greer, N.; Slinin, Y.; Ensrud, K.E. The Magnitude of Acute Serum Creatinine Increase After Cardiac Surgery and the Risk of Chronic Kidney Disease, Progression of Kidney Disease, and Death. Arch. Intern. Med. 2011, 171, 226-233. [CrossRef]

11. Mehta, S.; Chauhan, K.; Patel, A.; Patel, S.; Pinotti, R.; Nadkarni, G.N.; Parikh, C.R.; Coca, S.G. The prognostic importance of duration of AKI: A systematic review and meta-analysis. BMC Nephrol. 2018, 19, 91. [CrossRef] [PubMed]

12. Thakar, C.V.; Christianson, A.; Himmelfarb, J.; Leonard, A.C. Acute kidney injury episodes and chronic kidney disease risk in diabetes mellitus. Clin. J. Am. Soc. Nephrol. 2011, 6, 2567-2572. [CrossRef] [PubMed]

13. Devarajan, P.; Jefferies, J.L. Progression of chronic kidney disease after acute kidney injury. Prog. Pediatr. Cardiol. 2016, 41, 33-40. [CrossRef] [PubMed]

14. Uber, A.M.; Sutherland, S.M. Acute kidney injury in hospitalized children: Consequences and outcomes. Pediatr. Nephrol. Berl. Ger. 2018, 1-8. [CrossRef] [PubMed]

15. Sigurjonsdottir, V.K.; Chaturvedi, S.; Mammen, C.; Sutherland, S.M. Pediatric acute kidney injury and the subsequent risk for chronic kidney disease: Is there cause for alarm? Pediatr. Nephrol. Berl. Ger. 2018, 33, 2047-2055. [CrossRef]

16. Basile, D.P.; Bonventre, J.V.; Mehta, R.; Nangaku, M.; Unwin, R.; Rosner, M.H.; Kellum, J.A.; Ronco, C.; ADQI XIII Work Group. Progression after AKI: Understanding Maladaptive Repair Processes to Predict and Identify Therapeutic Treatments. J. Am. Soc. Nephrol. 2016, 27, 687-697. [CrossRef]

17. Bellomo, R.; Kellum, J.A.; Ronco, C. Acute kidney injury. Lancet 2012, 380, 756-766. [CrossRef]

18. Venkatachalam, M.A.; Griffin, K.A.; Lan, R.; Geng, H.; Saikumar, P.; Bidani, A.K. Acute kidney injury: A springboard for progression in chronic kidney disease. Am. J. Physiol. Renal Physiol. 2010, 298, F1078-F1094. [CrossRef]

19. Rodriguez-Romo, R.; Benitez, K.; Barrera-Chimal, J.; Perez-Villalva, R.; Gomez, A.; Aguilar-Leon, D.; Rangel-Santiago, J.F.; Huerta, S.; Gamba, G.; Uribe, N.; et al. AT1 receptor antagonism before ischemia prevents the transition of acute kidney injury to chronic kidney disease. Kidney Int. 2016, 89, 363-373. [CrossRef]

20. Chou, Y.-H.; Chu, T.-S.; Lin, S.-L. Role of renin-angiotensin system in acute kidney injury-chronic kidney disease transition. Nephrol. Carlton Vic 2018, 23, 121-125. [CrossRef] 
21. Grgic, I.; Campanholle, G.; Bijol, V.; Wang, C.; Sabbisetti, V.S.; Ichimura, T.; Humphreys, B.D.; Bonventre, J.V. Targeted proximal tubule injury triggers interstitial fibrosis and glomerulosclerosis. Kidney Int. 2012, 82, 172-183. [CrossRef] [PubMed]

22. Ferenbach, D.A.; Bonventre, J.V. Mechanisms of maladaptive repair after AKI leading to accelerated kidney ageing and CKD. Nat. Rev. Nephrol. 2015, 11, 264-276. [CrossRef] [PubMed]

23. Venkatachalam, M.A.; Weinberg, J.M.; Kriz, W.; Bidani, A.K. Failed Tubule Recovery, AKI-CKD Transition, and Kidney Disease Progression. J. Am. Soc. Nephrol. 2015, 26, 1765-1776. [CrossRef] [PubMed]

24. Basile, D.P. The endothelial cell in ischemic acute kidney injury: Implications for acute and chronic function. Kidney Int. 2007, 72, 151-156. [CrossRef] [PubMed]

25. Basile, D.P.; Collett, J.A.; Yoder, M.C. Endothelial colony-forming cells and pro-angiogenic cells: Clarifying definitions and their potential role in mitigating acute kidney injury. Acta. Physiol. Oxf. Engl. 2018, 222, e12914. [CrossRef] [PubMed]

26. Lech, M.; Gröbmayr, R.; Ryu, M.; Lorenz, G.; Hartter, I.; Mulay, S.R.; Susanti, H.E.; Kobayashi, K.S.; Flavell, R.A.; Anders, H.-J. Macrophage phenotype controls long-term AKI outcomes-Kidney regeneration versus atrophy. J. Am. Soc. Nephrol. 2014, 25, 292-304. [CrossRef] [PubMed]

27. Anders, H.-J.; Schaefer, L. Beyond Tissue Injury-Damage-Associated Molecular Patterns, Toll-Like Receptors, and Inflammasomes Also Drive Regeneration and Fibrosis. J. Am. Soc. Nephrol. 2014, 25, 1387-1400. [CrossRef]

28. Belliere, J.; Casemayou, A.; Ducasse, L.; Zakaroff-Girard, A.; Martins, F.; Iacovoni, J.S.; Guilbeau-Frugier, C.; Buffin-Meyer, B.; Pipy, B.; Chauveau, D.; et al. Specific Macrophage Subtypes Influence the Progression of Rhabdomyolysis-Induced Kidney Injury. J. Am. Soc. Nephrol. 2015, 26, 1363-1377. [CrossRef] [PubMed]

29. Jang, H.R.; Rabb, H. Immune cells in experimental acute kidney injury. Nat. Rev. Nephrol. 2015, 11, 88-101. [CrossRef]

30. Sato, Y.; Yanagita, M. Immune cells and inflammation in AKI to CKD progression. Am. J. Physiol. Renal Physiol. 2018, 315, 1501-1512. [CrossRef]

31. Gomez, I.G.; Duffield, J.S. The FOXD1 lineage of kidney perivascular cells and myofibroblasts: Functions and responses to injury. Kidney Int. Suppl. 2014, 4, 26-33. [CrossRef] [PubMed]

32. Mack, M.; Yanagita, M. Origin of myofibroblasts and cellular events triggering fibrosis. Kidney Int. 2015, 87, 297-307. [CrossRef] [PubMed]

33. Nakamura, J.; Sato, Y.; Kitai, Y.; Wajima, S.; Yamamoto, S.; Oguchi, A.; Yamada, R.; Kaneko, K.; Kondo, M.; Uchino, E.; et al. Myofibroblasts acquire retinoic acid-producing ability during fibroblast-to-myofibroblast transition following kidney injury. Kidney Int. 2019, 95, 526-539. [CrossRef] [PubMed]

34. Kaissling, B.; Lehir, M.; Kriz, W. Renal epithelial injury and fibrosis. Biochim. Biophys. Acta 2013, 1832, 931-939. [CrossRef] [PubMed]

35. Liu, B.-C.; Tang, T.-T.; Lv, L.-L.; Lan, H.-Y. Renal tubule injury: A driving force toward chronic kidney disease. Kidney Int. 2018, 93, 568-579. [CrossRef]

36. Patschan, D.; Kribben, A.; Müller, G.A. Postischemic microvasculopathy and endothelial progenitor cell-based therapy in ischemic AKI: Update and perspectives. Am. J. Physiol.-Ren. Physiol. 2016, 311, 382-394. [CrossRef]

37. Sradnick, J.; Rong, S.; Luedemann, A.; Parmentier, S.P.; Bartaun, C.; Todorov, V.T.; Gueler, F.; Hugo, C.P.; Hohenstein, B. Extrarenal Progenitor Cells Do Not Contribute to Renal Endothelial Repair. J. Am. Soc. Nephrol. 2016, 27, 1714-1726. [CrossRef]

38. Kumar, S. Cellular and molecular pathways of renal repair after acute kidney injury. Kidney Int. 2018, 93, 27-40. [CrossRef]

39. Tanaka, S.; Tanaka, T.; Nangaku, M. Hypoxia as a key player in the AKI-to-CKD transition. Am. J. Physiol. Renal Physiol. 2014, 307, 1187-1195. [CrossRef]

40. Chade, A.R. Vascular Endothelial Growth Factor Therapy for the Kidney: Are We There Yet? J. Am. Soc. Nephrol. 2016, 27, 1-3. [CrossRef]

41. Chade, A.R.; Tullos, N.A.; Harvey, T.W.; Mahdi, F.; Bidwell, G.L. Renal Therapeutic Angiogenesis Using a Bioengineered Polymer-Stabilized Vascular Endothelial Growth Factor Construct. J. Am. Soc. Nephrol. 2016, 27, 1741-1752. [CrossRef] [PubMed]

42. Hörbelt, M.; Lee, S.-Y.; Mang, H.E.; Knipe, N.L.; Sado, Y.; Kribben, A.; Sutton, T.A. Acute and chronic microvascular alterations in a mouse model of ischemic acute kidney injury. Am. J. Physiol.-Ren. Physiol. 2007, 293, 688-695. [CrossRef] [PubMed] 
43. Kapitsinou, P.P.; Sano, H.; Michael, M.; Kobayashi, H.; Davidoff, O.; Bian, A.; Yao, B.; Zhang, M.-Z.; Harris, R.C.; Duffy, K.J.; et al. Endothelial HIF-2 mediates protection and recovery from ischemic kidney injury. J. Clin. Invest. 2014, 124, 2396-2409. [CrossRef] [PubMed]

44. Perry, H.M.; Huang, L.; Ye, H.; Liu, C.; Sung, S.J.; Lynch, K.R.; Rosin, D.L.; Bajwa, A.; Okusa, M.D. Endothelial Sphingosine 1-Phosphate Receptor-1 Mediates Protection and Recovery from Acute Kidney Injury. J. Am. Soc. Nephrol. 2016, 27, 3383-3393. [CrossRef] [PubMed]

45. Tanaka, T.; Wiesener, M.; Bernhardt, W.; Eckardt, K.-U.; Warnecke, C. The human HIF (hypoxia-inducible factor)-3 $\alpha$ gene is a HIF-1 target gene and may modulate hypoxic gene induction. Biochem. J. 2009, 424, 143-151. [CrossRef] [PubMed]

46. Vasko, R.; Xavier, S.; Chen, J.; Lin, C.H.S.; Ratliff, B.; Rabadi, M.; Maizel, J.; Tanokuchi, R.; Zhang, F.; Cao, J.; et al. Endothelial Sirtuin 1 Deficiency Perpetrates Nephrosclerosis through Downregulation of Matrix Metalloproteinase-14: Relevance to Fibrosis of Vascular Senescence. J. Am. Soc. Nephrol. 2014, 25, $276-291$. [CrossRef] [PubMed]

47. Kida, Y.; Zullo, J.A.; Goligorsky, M.S. Endothelial sirtuin 1 inactivation enhances capillary rarefaction and fibrosis following kidney injury through Notch activation. Biochem. Biophys. Res. Commun. 2016, 478, 1074-1079. [CrossRef] [PubMed]

48. Basile, D.P.; Friedrich, J.L.; Spahic, J.; Knipe, N.; Mang, H.; Leonard, E.C.; Changizi-Ashtiyani, S.; Bacallao, R.L.; Molitoris, B.A.; Sutton, T.A. Impaired endothelial proliferation and mesenchymal transition contribute to vascular rarefaction following acute kidney injury. Am. J. Physiol.-Ren. Physiol. 2011, 300, 721-733. [CrossRef]

49. Xavier, S.; Vasko, R.; Matsumoto, K.; Zullo, J.A.; Chen, R.; Maizel, J.; Chander, P.N.; Goligorsky, M.S. Curtailing Endothelial TGF- $\beta$ Signaling Is Sufficient to Reduce Endothelial-Mesenchymal Transition and Fibrosis in CKD. J. Am. Soc. Nephrol. 2015, 26, 817-829. [CrossRef]

50. Kramann, R.; Wongboonsin, J.; Chang-Panesso, M.; Machado, F.G.; Humphreys, B.D. Gli1 ${ }^{+}$Pericyte Loss Induces Capillary Rarefaction and Proximal Tubular Injury. J. Am. Soc. Nephrol. 2017, 28, 776-784. [CrossRef]

51. Betsholtz, C. Insight into the physiological functions of PDGF through genetic studies in mice. Cytokine Growth Factor Rev. 2004, 15, 215-228. [CrossRef] [PubMed]

52. Sundberg, C.; Kowanetz, M.; Brown, L.F.; Detmar, M.; Dvorak, H.F. Stable expression of angiopoietin-1 and other markers by cultured pericytes: Phenotypic similarities to a subpopulation of cells in maturing vessels during later stages of angiogenesis in vivo. Lab. Investig. J. Tech. Methods Pathol. 2002, 82, 387-401. [CrossRef]

53. Carvalho, R.L.C. Defective paracrine signalling by TGF in yolk sac vasculature of endoglin mutant mice: A paradigm for hereditary haemorrhagic telangiectasia. Development 2004, 131, 6237-6247. [CrossRef] [PubMed]

54. Benjamin, L.E.; Hemo, I.; Keshet, E. A plasticity window for blood vessel remodelling is defined by pericyte coverage of the preformed endothelial network and is regulated by PDGF-B and VEGF. Dev. Camb. Engl. 1998, 125, 1591-1598.

55. Chae, S.-S.; Paik, J.-H.; Allende, M.L.; Proia, R.L.; Hla, T. Regulation of limb development by the sphingosine 1-phosphate receptor S1p1/EDG-1 occurs via the hypoxia/VEGF axis. Dev. Biol. 2004, 268, 441-447. [CrossRef] [PubMed]

56. Anders, H.-J. Immune system modulation of kidney regeneration-mechanisms and implications. Nat. Rev. Nephrol. 2014, 10, 347-358. [CrossRef]

57. Stamatiades, E.G.; Tremblay, M.-E.; Bohm, M.; Crozet, L.; Bisht, K.; Kao, D.; Coelho, C.; Fan, X.; Yewdell, W.T.; Davidson, A.; et al. Immune Monitoring of Trans-endothelial Transport by Kidney-Resident Macrophages. Cell 2016, 166, 991-1003. [CrossRef]

58. Karasawa, K.; Asano, K.; Moriyama, S.; Ushiki, M.; Monya, M.; Iida, M.; Kuboki, E.; Yagita, H.; Uchida, K.; Nitta, K.; et al. Vascular-Resident CD169-Positive Monocytes and Macrophages Control Neutrophil Accumulation in the Kidney with Ischemia-Reperfusion Injury. J. Am. Soc. Nephrol. 2015, 26, 896-906. [CrossRef]

59. Mantovani, A.; Sica, A.; Sozzani, S.; Allavena, P.; Vecchi, A.; Locati, M. The chemokine system in diverse forms of macrophage activation and polarization. Trends Immunol. 2004, 25, 677-686. [CrossRef]

60. Martinez, F.O.; Gordon, S. The M1 and M2 paradigm of macrophage activation: Time for reassessment. F1000Prime Rep. 2014, 6, 13. [CrossRef] 
61. Clements, M.; Gershenovich, M.; Chaber, C.; Campos-Rivera, J.; Du, P.; Zhang, M.; Ledbetter, S.; Zuk, A. Differential Ly6C Expression after Renal Ischemia-Reperfusion Identifies Unique Macrophage Populations. J. Am. Soc. Nephrol. 2016, 27, 159-170. [CrossRef] [PubMed]

62. Jang, H.-S.; Kim, J.; Park, Y.-K.; Park, K.M. Infiltrated Macrophages Contribute to Recovery after Ischemic Injury But Not to Ischemic Preconditioning in Kidneys. Transplantation 2008, 85, 447-455. [CrossRef] [PubMed]

63. Xu, M.-J.; Feng, D.; Wang, H.; Guan, Y.; Yan, X.; Gao, B. IL-22 Ameliorates Renal Ischemia-Reperfusion Injury by Targeting Proximal Tubule Epithelium. J. Am. Soc. Nephrol. 2014, 25, 967-977. [CrossRef] [PubMed]

64. Chiba, T.; Skrypnyk, N.I.; Skvarca, L.B.; Penchev, R.; Zhang, K.X.; Rochon, E.R.; Fall, J.L.; Paueksakon, P.; Yang, H.; Alford, C.E.; et al. Retinoic Acid Signaling Coordinates Macrophage-Dependent Injury and Repair after AKI. J. Am. Soc. Nephrol. 2016, 27, 495-508. [CrossRef] [PubMed]

65. Lin, S.-L.; Li, B.; Rao, S.; Yeo, E.-J.; Hudson, T.E.; Nowlin, B.T.; Pei, H.; Chen, L.; Zheng, J.J.; Carroll, T.J.; et al. Macrophage Wnt7b is critical for kidney repair and regeneration. Proc. Natl. Acad. Sci. USA 2010, 107, 4194-4199. [CrossRef] [PubMed]

66. Zhou, D.; Tan, R.J.; Fu, H.; Liu, Y. Wnt/ $\beta$-catenin signaling in kidney injury and repair: A double-edged sword. Lab. Invest. 2016, 96, 156-167. [CrossRef]

67. Tan, R.J.; Zhou, D.; Zhou, L.; Liu, Y. Wnt/ $\beta$-catenin signaling and kidney fibrosis. Kidney Int. Suppl. 2014, 4, 84-90. [CrossRef] [PubMed]

68. Zhang, M.-Z.; Yao, B.; Yang, S.; Jiang, L.; Wang, S.; Fan, X.; Yin, H.; Wong, K.; Miyazawa, T.; Chen, J.; et al. CSF-1 signaling mediates recovery from acute kidney injury. J. Clin. Invest. 2012, 122, 4519-4532. [CrossRef]

69. Baek, J.-H.; Zeng, R.; Weinmann-Menke, J.; Valerius, M.T.; Wada, Y.; Ajay, A.K.; Colonna, M.; Kelley, V.R. IL-34 mediates acute kidney injury and worsens subsequent chronic kidney disease. J. Clin. Invest. 2015, 125, 3198-3214. [CrossRef]

70. Lee, S.A.; Noel, S.; Sadasivam, M.; Hamad, A.R.A.; Rabb, H. Role of Immune Cells in Acute Kidney Injury and Repair. Nephron 2017, 137, 282-286. [CrossRef]

71. Kim, M.-G.; Koo, T.Y.; Yan, J.-J.; Lee, E.; Han, K.H.; Jeong, J.C.; Ro, H.; Kim, B.S.; Jo, S.-K.; Oh, K.H.; et al. IL-2/Anti-IL-2 Complex Attenuates Renal Ischemia-Reperfusion Injury through Expansion of Regulatory T Cells. J. Am. Soc. Nephrol. 2013, 24, 1529-1536. [CrossRef] [PubMed]

72. Gandolfo, M.T.; Jang, H.R.; Bagnasco, S.M.; Ko, G.-J.; Agreda, P.; Satpute, S.R.; Crow, M.T.; King, L.S.; Rabb, H. Foxp $^{+}$regulatory T cells participate in repair of ischemic acute kidney injury. Kidney Int. 2009, 76, 717-729. [CrossRef] [PubMed]

73. Baudoux, T.; Husson, C.; De Prez, E.; Jadot, I.; Antoine, M.-H.; Nortier, J.L.; Hougardy, J.-M. CD4+ and CD8+ T Cells Exert Regulatory Properties During Experimental Acute Aristolochic Acid Nephropathy. Sci. Rep. 2018, 8, 5334. [CrossRef] [PubMed]

74. Renner, B.; Strassheim, D.; Amura, C.R.; Kulik, L.; Ljubanovic, D.; Glogowska, M.J.; Takahashi, K.; Carroll, M.C.; Holers, V.M.; Thurman, J.M. B Cell Subsets Contribute to Renal Injury and Renal Protection after Ischemia/Reperfusion. J. Immunol. 2010, 185, 4393-4400. [CrossRef] [PubMed]

75. Klingberg, F.; Hinz, B.; White, E.S. The myofibroblast matrix: Implications for tissue repair and fibrosis: The myofibroblast matrix. J. Pathol. 2013, 229, 298-309. [CrossRef] [PubMed]

76. Mackensen-Haen, S.; Bader, R.; Grund, K.E.; Bohle, A. Correlations between renal cortical interstitial fibrosis, atrophy of the proximal tubules and impairment of the glomerular filtration rate. Clin. Nephrol. 1981, 15, 167-171. [PubMed]

77. Picken, M.; Long, J.; Williamson, G.A.; Polichnowski, A.J. Progression of Chronic Kidney Disease After Acute Kidney Injury: Role of Self-Perpetuating Versus Hemodynamic-Induced Fibrosis. Hypertens. Dallas Tex 1979 2016, 68, 921-928. [CrossRef] [PubMed]

78. Takaori, K.; Nakamura, J.; Yamamoto, S.; Nakata, H.; Sato, Y.; Takase, M.; Nameta, M.; Yamamoto, T.; Economides, A.N.; Kohno, K.; et al. Severity and Frequency of Proximal Tubule Injury Determines Renal Prognosis. J. Am. Soc. Nephrol. 2016, 27, 2393-2406. [CrossRef]

79. Sato, Y.; Mii, A.; Hamazaki, Y.; Fujita, H.; Nakata, H.; Masuda, K.; Nishiyama, S.; Shibuya, S.; Haga, H.; Ogawa, O.; et al. Heterogeneous fibroblasts underlie age-dependent tertiary lymphoid tissues in the kidney. JCI Insight 2016, 1, e87680. [CrossRef]

80. Allinovi, M.; de Chiara, L.; Angelotti, M.L.; Becherucci, F.; Romagnani, P. Anti-fibrotic treatments: A review of clinical evidence. Matrix Biol. 2018, 68-69, 333-354. [CrossRef] 
81. De Chiara, L.; Romagnani, P. Tubule repair: With a little help from my "unexpected" friends. Kidney Int. 2019, 95, 487-489. [CrossRef] [PubMed]

82. Sharfuddin, A.A.; Molitoris, B.A. Pathophysiology of ischemic acute kidney injury. Nat. Rev. Nephrol. 2011, 7, 189-200. [CrossRef] [PubMed]

83. Funk, J.A.; Schnellmann, R.G. Persistent disruption of mitochondrial homeostasis after acute kidney injury. Am. J. Physiol. Renal Physiol. 2012, 302, 853-864. [CrossRef] [PubMed]

84. Wang, Y.; Chang, J.; Yao, B.; Niu, A.; Kelly, E.; Breeggemann, M.C.; Abboud Werner, S.L.; Harris, R.C.; Zhang, M.-Z. Proximal tubule-derived colony stimulating factor-1 mediates polarization of renal macrophages and dendritic cells, and recovery in acute kidney injury. Kidney Int. 2015, 88, 1274-1282. [CrossRef] [PubMed]

85. Huen, S.C.; Huynh, L.; Marlier, A.; Lee, Y.; Moeckel, G.W.; Cantley, L.G. GM-CSF Promotes Macrophage Alternative Activation after Renal Ischemia/Reperfusion Injury. J. Am. Soc. Nephrol. 2015, 26, 1334-1345. [CrossRef]

86. Kramann, R.; Kusaba, T.; Humphreys, B.D. Who regenerates the kidney tubule? Nephrol. Dial. Transplant. Off. Publ. Eur. Dial. Transpl. Assoc. -Eur. Ren. Assoc. 2015, 30, 903-910. [CrossRef] [PubMed]

87. Chang-Panesso, M.; Humphreys, B.D. Cellular plasticity in kidney injury and repair. Nat. Rev. Nephrol. 2017, 13, 39-46. [CrossRef]

88. Witzgall, R.; Brown, D.; Schwarz, C.; Bonventre, J.V. Localization of proliferating cell nuclear antigen, vimentin, c-Fos, and clusterin in the postischemic kidney. Evidence for a heterogenous genetic response among nephron segments, and a large pool of mitotically active and dedifferentiated cells. J. Clin. Invest. 1994, 93, 2175-2188. [CrossRef]

89. Grande, M.T.; Sánchez-Laorden, B.; López-Blau, C.; De Frutos, C.A.; Boutet, A.; Arévalo, M.; Rowe, R.G.; Weiss, S.J.; López-Novoa, J.M.; Nieto, M.A. Snail1-induced partial epithelial-to-mesenchymal transition drives renal fibrosis in mice and can be targeted to reverse established disease. Nat. Med. 2015, 21, 989-997. [CrossRef]

90. Lovisa, S.; LeBleu, V.S.; Tampe, B.; Sugimoto, H.; Vadnagara, K.; Carstens, J.L.; Wu, C.-C.; Hagos, Y.; Burckhardt, B.C.; Pentcheva-Hoang, T.; et al. Epithelial-to-mesenchymal transition induces cell cycle arrest and parenchymal damage in renal fibrosis. Nat. Med. 2015, 21, 998-1009. [CrossRef]

91. Vogetseder, A.; Karadeniz, A.; Kaissling, B.; Le Hir, M. Tubular cell proliferation in the healthy rat kidney. Histochem. Cell Biol. 2005, 124, 97-104. [CrossRef] [PubMed]

92. Vogetseder, A.; Picard, N.; Gaspert, A.; Walch, M.; Kaissling, B.; le Hir, M. Proliferation capacity of the renal proximal tubule involves the bulk of differentiated epithelial cells. Am. J. Physiol.-Cell Physiol. 2008, 294, 22-28. [CrossRef] [PubMed]

93. Yang, L.; Besschetnova, T.Y.; Brooks, C.R.; Shah, J.V.; Bonventre, J.V. Epithelial cell cycle arrest in G2/M mediates kidney fibrosis after injury. Nat. Med. 2010, 16, 535-543. [CrossRef] [PubMed]

94. Canaud, G.; Bonventre, J.V. Cell cycle arrest and the evolution of chronic kidney disease from acute kidney injury. Nephrol. Dial. Transplant. 2015, 30, 575-583. [CrossRef] [PubMed]

95. Lazzeri, E.; Angelotti, M.L.; Peired, A.; Conte, C.; Marschner, J.A.; Maggi, L.; Mazzinghi, B.; Lombardi, D.; Melica, M.E.; Nardi, S.; et al. Endocycle-related tubular cell hypertrophy and progenitor proliferation recover renal function after acute kidney injury. Nat. Commun. 2018, 9, 1344. [CrossRef] [PubMed]

96. Lazzeri, E.; Angelotti, M.L.; Conte, C.; Anders, H.-J.; Romagnani, P. Surviving Acute Organ Failure: Cell Polyploidization and Progenitor Proliferation. Trends Mol. Med. 2019, 25, 366-381. [CrossRef] [PubMed]

97. Lombardi, D.; Becherucci, F.; Romagnani, P. How much can the tubule regenerate and who does it? An open question. Nephrol. Dial. Transplant. 2016, 31, 1243-1250. [CrossRef] [PubMed]

98. Lindgren, D.; Boström, A.-K.; Nilsson, K.; Hansson, J.; Sjölund, J.; Möller, C.; Jirström, K.; Nilsson, E.; Landberg, G.; Axelson, H.; et al. Isolation and characterization of progenitor-like cells from human renal proximal tubules. Am. J. Pathol. 2011, 178, 828-837. [CrossRef] [PubMed]

99. Angelotti, M.L.; Ronconi, E.; Ballerini, L.; Peired, A.; Mazzinghi, B.; Sagrinati, C.; Parente, E.; Gacci, M.; Carini, M.; Rotondi, M.; et al. Characterization of renal progenitors committed toward tubular lineage and their regenerative potential in renal tubular injury. Stem Cells Dayt. Ohio 2012, 30, 1714-1725. [CrossRef]

100. Smeets, B.; Boor, P.; Dijkman, H.; Sharma, S.V.; Jirak, P.; Mooren, F.; Berger, K.; Bornemann, J.; Gelman, I.H.; Floege, J.; et al. Proximal tubular cells contain a phenotypically distinct, scattered cell population involved in tubular regeneration: Phenotypically distinct proximal tubular cells. J. Pathol. 2013, 229, 645-659. [CrossRef] 
101. Kumar, S.; Liu, J.; Pang, P.; Krautzberger, A.M.; Reginensi, A.; Akiyama, H.; Schedl, A.; Humphreys, B.D.; McMahon, A.P. Sox9 Activation Highlights a Cellular Pathway of Renal Repair in the Acutely Injured Mammalian Kidney. Cell Rep. 2015, 12, 1325-1338. [CrossRef] [PubMed]

102. Kang, H.M.; Huang, S.; Reidy, K.; Han, S.H.; Chinga, F.; Susztak, K. Sox9-Positive Progenitor Cells Play a Key Role in Renal Tubule Epithelial Regeneration in Mice. Cell Rep. 2016, 14, 861-871. [CrossRef] [PubMed]

103. Berger, K.; Bangen, J.-M.; Hammerich, L.; Liedtke, C.; Floege, J.; Smeets, B.; Moeller, M.J. Origin of regenerating tubular cells after acute kidney injury. Proc. Natl. Acad. Sci. USA 2014, 111, 1533-1538. [CrossRef] [PubMed]

104. Romagnani, P.; Lasagni, L.; Remuzzi, G. Renal progenitors: An evolutionary conserved strategy for kidney regeneration. Nat. Rev. Nephrol. 2013, 9, 137-146. [CrossRef] [PubMed]

105. Rinkevich, Y.; Montoro, D.T.; Contreras-Trujillo, H.; Harari-Steinberg, O.; Newman, A.M.; Tsai, J.M.; Lim, X.; Van-Amerongen, R.; Bowman, A.; Januszyk, M.; et al. In Vivo Clonal Analysis Reveals Lineage-Restricted Progenitor Characteristics in Mammalian Kidney Development, Maintenance, and Regeneration. Cell Rep. 2014, 7, 1270-1283. [CrossRef] [PubMed]

106. Humphreys, B.D.; Valerius, M.T.; Kobayashi, A.; Mugford, J.W.; Soeung, S.; Duffield, J.S.; McMahon, A.P.; Bonventre, J.V. Intrinsic Epithelial Cells Repair the Kidney after Injury. Cell Stem Cell 2008, 2, $284-291$. [CrossRef] [PubMed]

107. Shu, Z.; Row, S.; Deng, W.-M. Endoreplication: The Good, the Bad, and the Ugly. Trends Cell Biol. 2018, 28, 465-474. [CrossRef]

(C) 2019 by the authors. Licensee MDPI, Basel, Switzerland. This article is an open access article distributed under the terms and conditions of the Creative Commons Attribution (CC BY) license (http://creativecommons.org/licenses/by/4.0/). 